УДК 346.91

\author{
О. Л. Соловйов \\ orcid.org/0000-0002-0017-9384 \\ аспірант кафедри господарсько-правових дисииплін та економічної безпеки \\ Донеиького юридичного інституту \\ Міністерства внутрішніх справ України
}

\title{
ОСОБЛИВОСТІ РОЗГЛЯДУ СПРАВИ У СПРОЩЕНОМУ ПОЗОВНОМУ ПРОВАДЖЕННІ В ГОСПОДАРСЬКОМУ СУДОЧИНСТВІ
}

Постановка проблеми. Нагальними викликами для сучасної юриспруденції є удосконалення процедур розгляду та вирішення правових спорів, в тому числі шляхом застосування процедури спрощеного розгляду, впровадження в правозастосовну практику ідеології примирення та доцільне розширення диспозитивних засад у судовому процесі.

Стаття 2 Господарського процесуального кодексу України (далі - ГПК України) визначає, що завданням господарського судочинства $є$ справедливе, неупереджене та своєчасне вирішення судом спорів, пов'язаних зі здійсненням господарської діяльності, та розгляд інших справ, віднесених до юрисдикції господарського суду, з метою ефективного захисту порушених, невизнаних або оспорюваних прав і законних інтересів фізичних та юридичних осіб, держави [1].

Питання своєчасності та оперативного розгляду справи є визначальними для забезпечення не тільки ефективного розвитку господарської діяльності, а й економіки держави загалом. ГПК України надає можливості захисту господарської діяльності та закріплює інститут спрощеного позовного провадження. Існування такого інституту пов'язано з необхідністю оптимізації судочинства з метою розгляду деяких категорій господарських спорів без обтяжливих процедур.

Необхідно зазначити, що стосовно цього інституту позиції не тільки вчених, а й практиків $\epsilon$ неоднозначними, оскільки практичні аспекти застосування відповідних норм ГПК України пов'язані з виникненням суперечностей, неоднозначним тлумаченням законодавчих положень щодо спрощеного провадження. Саме тому дослідження інституту спрощеного провадження, виявлення та окреслення його особливостей є актуальним через необхідність вдосконалення відповідних норм ГПК України.

Аналіз останніх досліджень i публікацій. Проблематику спрощеного позовного провадження предметом свого розгляду зробили вчені О.А. Беляневич, В.І. Бобрик, А.А. Бутирський, С.Ф. Демченко, А.О. Згама, С.В. Масловський, Л.М. Ніколенко, О.П. Подцерковний, В.В. Рєзнікова, А.В. Смітюх, Т.Д. Суярко, О.С. Фонова,
В.С. Щербина та інші. Але в умовах продовження судової реформи та оновлення процесуального законодавства виникла необхідність визначення особливостей розгляду справ у спрощеному позовному провадженні.

Метою статті є дослідження особливостей розгляду справ у спрощеному позовному провадженні в господарському судочинстві в умовах реформування законодавства із застосуванням порівняльного аналізу.

Виклад основного матеріалу дослідження. Відповідно до ст. 12 ГПК України метою спрощеного провадження як однієї з форм господарського судочинства $є$ швидке вирішення справи. 3 аналізу ст.ст. 12 та 247 ГПК України можна зробити висновок, що в межах цього провадження можуть бути розглянуті малозначні справи; справи незначної складності; інші категорії справ, які не належать до справ, визначених в ч. 4 ст. 247 ГПК України.

Щодо визначення "малозначна справа», то законодавство не містить такого поняття, воно відноситься до оціночних понять, щодо яких може бути висловлюване різне тлумачення. Практика використання оціночних понять $є$ неоднозначною, тому що для визначення дефініції можуть бути застосовані різні поняття та складники. Дотриманню вимог закону суб'єктами правозастосування значною мірою сприяє зрозумілість, точність і конкретність законодавчих приписів. Точність вважається однією з найважливіших властивостей мови законодавчого акту. Не випадково Ф. Бекон пов'язував точність закону з його справедливістю [2, с. 128].

Спрощене позовне провадження розглядається вченими як додаткова спрощена форма розгляду й вирішення справи, спрямована на оптимізацію та узгодження судового розгляду з метою зменшення навантаження на суди [3, с. 46]. Необхідно зазначити, що прискорення вирішення певних категорій справ завдяки спрощенню основних складників процесу не знижує рівня юридичних гарантій [4, с. 219]. Спрощене провадження також закріплюе роль суду в суспільстві через більш коротку та просту процедуру [5, с. 104], що здійснюеться за рахунок оптимізації етапів і строків судового 
провадження, порядку притягнення учасників процесу та зменшення кількості процесуальних дій [6, с. 21]. Саме прискорений розгляд можна визначити як одну з основних особливостей спрощеного провадження.

Існування інституту спрощеного позовного провадження підкреслює прагнення України запровадити у господарське судочинство європейські стандарти правосуддя. Багато країн-членів Європейського Союзу застосовують спрощені процедури розгляду справ, які пов'язані з невеликою сумою позову та можуть бути «різних видів, наприклад, ухвалення рішення без проведення судового засідання або з проведенням останнього в кабінеті судді, ухвалення рішення суддею одноособово, спрощене рішення тощо» [7, с. 215]. На загальноєвропейському (наднаціональному) рівні визначена процедура розгляду дрібних справ, які мають транскордонний характер (European Small Claims Procedure) [8]. Тобто розвиток спрощеного провадження є продовженням прагнення України запровадити європейські стандарти правосуддя у національне законодавство з метою ефективного та оперативного розгляду справ.

Т.Д. Суярко зазначає, що «умовами, які дозволяють розглядати справу у порядку спрощеного провадження, є відсутність заперечень з боку відповідача, наявність згоди сторін на розгляд справи у спрощеному провадженні, тобто ті події, які ще не настали і настання яких (або ненастання) не можливо спрогнозувати. Саме наявність у сукупності підстав та умов дозволяє визначити необхідні та достатні передумови для розгляду справи в порядку спрощеного провадження» [9, с. 155].

Відповідно ст. 248 ГПК України суд розглядає справи у порядку спрощеного позовного провадження протягом розумного строку, але не більше 60 днів із дня відкриття провадження у справі. Стаття 247 ГПК України визначає, що при вирішенні питання про розгляд справи в порядку спрощеного позовного провадження суд враховує ціну позову; значення справи для сторін; обраний позивачем спосіб захисту; категорію та складність справи; обсяг і характер доказів у справі, в тому числі, чи потрібно у справі призначити експертизу, викликати свідків; кількість сторін та інших учасників справи; чи становить розгляд справи значний суспільний інтерес; думку сторін щодо необхідності розгляду справи за правилами спрощеного позовного провадження [1]. Тому особливістю спрощеного провадження є попереднє визначення умов, за яких суддя приймає рішення щодо розгляду справи в порядку спрощеного позовного провадження.

Аналізуючи критерії віднесення справи до розгляду в порядку спрощеного провадження, можна визначити, що критерії мають оціночний характер, за винятком ціни позову. Суд повинен вра- ховувати, що ціна не може бути вищою 500 розмірів прожиткового мінімуму для працездатних осіб, інакше справа може бути розглянута лише за правилами загального позовного провадження. Якщо ціна позову не перевищує 100 розмірів прожиткового мінімуму для працездатних осіб (станом на 01 січня 2021 року - 227000 гривень), то справа розглядається за правилами спрощеного позовного провадження судом обов'язково. Тобто, якщо ціна позову від 100 до 500 розмірів прожиткового мінімуму для працездатних осіб (станом на 01 січня 2021 року - 1135000 гривень), то суд має право, але не обов'язок розглядати такі справи в порядку спрощеного позовного провадження [10, с. 126]. При прийнятті судом рішення про розгляд справи в порядку спрощеного позовного провадження необхідно враховувати принцип рівноваги, а саме те, що ціна позову не повинна перевищувати розміру судових витрат.

Наукова література містить думку, що законодавча позиція щодо імперативного визначення категорій справ, які розглядаються в порядку спрощеного позовного провадження, має значні недоліки, її реалізація є недосяжною в певних випадках на практиці. Визначення малозначності справи виключно за ціною позову є спірним, оскільки ціна позову не свідчить про простий спосіб захисту, невеликий обсяг доказового матеріалу та можливість встановлення всіх обставин справи в скорочені строки [11, с. 86].

У п. 2 ч. 5 ст. 12 ГПК України зазначено, що суд має право прийняти рішення щодо розгляду будь-якої справи незначної складності у порядку спрощеного провадження за виключенням справ, які розглядаються тільки за правилами загального позовного провадження. Статті 249 та 250 ГПК України передбачають можливість прийняття судом рішення про початок спрощеного провадження за умови подання позивачем відповідного клопотання та відсутності заперечень позивача. Ці положення прискорюють розгляд справи, оскільки фактично в письмовому режимі відбувається узгодження питання щодо розгляду справи в порядку спрощеного провадження. Відсутність сторін при розгляді справи мінімізує зловживання сторонами своїми процесуальними правами з метою затягування судового розгляду та навмисного нез' явлення в судове засідання.

А.О. Згама підкреслює, що в порядку спрощеного провадження «права та законні інтереси учасників господарського процесу не обмежуються 3 огляду хоча б на те, що фактично доказова база господарського процесу побудована на письмових доказах, навіть пояснення представників сторін та інших осіб, які беруть участь у судовому процесі, на вимогу судді можуть бути викладені письмово. Спрощена процедура розгляду справи створить додаткові важелі впливу на дисци- 
плінованість учасників господарського процесу в контексті вчасності надання ними суду доказів та обгрунтування власної чіткої позиції у справі, дозволить прискорити отримання кінцевого результату по справі» [12, с. 54].

Визначаючи порядок розгляду справ в порядку спрощеного провадження, необхідно звернути увагу на кілька факторів: по-перше, оперативний або прискорений розгляд справ залежить від якості та повноти наданих позивачем документів, в тому числі доказів. Відповідно до ст. 251 ГПК України сторонами по справі подаються: від позивача - позовна заява та відповідь на відзив; від відповідача відзив і заперечення на відповідь на відзив; від третіх сторін - пояснення на позовну заяву та відзив. Клопотання при цьому передбачені лише в разі їх подання разом із позовної заявою. Згідно законодавства суд не зобов'язанний збирати докази, він оцінює та приймає рішення щодо їх достатності.

По-друге, при прийнятті рішення про перехід зі спрощеного провадження в загальне важливий кінцевий результат при розгляді справи як для позивача, так і для відповідача, оскільки це пов'язано з додатковими витратами на подання заперечення, а у разі його відхилення - на оскарження відповідної ухвали суду в порядку апеляційного провадження. Тому саме в цьому випадку сторони та учасники справи реалізують свою правову культуру та правосвідомість, а також рівень довіри до суду.

О. Бєлікова та Є. Бєлікова зазначають, що останнє є найбільш індикативним критерієм у вирішенні відповідачем питання щодо згоди на спрощене провадження. Річ у тім, що суд, не викликаючи сторін, все ж повинен вирішувати питання щодо процесуальної долі клопотань, заяв та інших документів, поданих разом із позовом або поданих як відповідь, відзив на позов чи заперечення на відзив. Тобто суд не може спитати думки сторін щодо допустимості тих чи інших процесуальних документів, їх релевантності чи належності до предмета доказування. Суд зобов' язаний самостійно вирішувати питання щодо задоволення тих чи інших клопотань, поданих сторонами, в тому числі і клопотань щодо необхідності витребування додаткових пояснень від третіх осіб, доказів або питань забезпечення позову чи доказів [13, с. 62-67]. Тобто, подальше удосконалення інституту спрощеного позовного провадження спрямовано на зменшення можливостей для зловживання процесуальними правами сторонами по справі та затягування процесу вирішення справи по суті.

По-третє, на підставі ч. 1 ст. 250 ГПК України питання про розгляд справи у порядку спрощеного позовного провадження суд вирішує в ухвалі про відкриття провадження у справі. Статті 251 та 252 ГПК України не передбачають прийняття судом інших проміжних ухвал, за винятком ух- вали щодо задоволення або відмови у задоволенні клопотання про перехід до розгляду справи за загальними правилами позовного провадження.

Особливістю спрощеного позовного провадження $€$ те, що згідно п. 2 ч. 3 ст. 251 ГПК України підготовче засідання при розгляді справи в порядку спрощеного провадження не проводиться. Перше судове засідання у справі проводиться не пізніше 30 днів із дня відкриття провадження у справі. За клопотанням сторони суд може відкласти розгляд справи з метою надання додаткового часу для подання відповіді на відзив та (або) заперечення, якщо вони не подані до першого судового засідання з поважних причин [1].

Також слід звернути увагу на особливості розгляду справи, які визначені ст. 252 ГПК України, а саме стосовно того, що суд досліджує докази і письмові пояснення, викладені у заявах по суті справи, а у випадку розгляду справи з повідомленням (викликом) учасників справи - також заслуховує їх усні пояснення. Судові дебати не проводяться. Тому можна зазначити, що спрощене провадження характеризується вилученням деяких стандартних складників, які властиві загальному позовному провадженню, але він все одно відповідає меті судочинства та здійснюється відповідно до встановленої процесуальної форми.

При розгляді справи у порядку спрощеного провадження свідки не викликаються. У випадку, якщо обставини, викладені свідком у заяві, суперечать іншим доказам або викликають у суду сумнів щодо їх достовірності, суд не бере до уваги показання свідка [1].

Ключовими ознаками спрощеного провадження в господарському судочинстві є завершеність процесуального циклу в межах певної судової інстанції; скорочення кількості процесуальних дій або системна зміна способу їх вчинення; звуження процесуальних можливостей суду й учасників процесу; обмеженість застосування щодо визначеного кола справ [14, с. 96]. Водночас введення спрощеного провадження не повинно суперечити цілям процесу загалом. Інші інтереси, наприклад, спрощення провадження для самого суду, не повинні бути пріоритетом під час впровадження спрощених процедур [15, с. 9].

Розгляд справи у формі спрощеного провадження здійснюється на основі принципів господарського судочинства, які характеризуються окремими особливостями їх реалізації. 3 огляду на те, що реалізація цих принципів є важливою гарантією справедливого розгляду і вирішення справи, на нашу думку, застосування спрощеного провадження має бути узгодженим із позицією сторін, а безальтернативність розгляду справи у спрощеному провадженні є неприпустимою без впровадження для них додаткових процесуальних можливостей [16, с. 62-70]. 
Висновки. На підставі зазначеного вище можна зазначити, що удосконалення інституту спрощеного провадження відповідно до визначених європейських стандартів і принципів буде сприяти не тільки ефективному та справедливому розгляду справи, а й підвищенню правової культури, відповідальності та сумлінності учасників справи. На законодавчому рівні повинна бути визначена можливість розширення переліку справ, які суд може розглянути в порядку спрощеного позовного провадження.

До основних особливостей спрощеного позовного провадження можна віднести особливу процесуальну форму, яка грунтується на прискореному розгляді справи; добровільність застосування зацікавленими особами; визначення передумов розгляду у спрощеному провадженні в ГПК України; особливий порядок застосування доказів; особливий порядок перегляду судових рішень, ухвалених за результатами розгляду справи.

\section{Jimepamypa}

1. Господарський процесуальний кодекс України : Закон України від 06 листопада 1991 року. Oфiиійний веб-портал Верховної Ради України. URL: https://zakon.rada.gov.ua/laws/show/1798-12.

2. Бэкон Ф. О достоинстве и приумножении наук. M., $1977.567 \mathrm{c.}$

3. Фурса С.Я., Фурса Є.І. Новітня концепція спрощеного провадження в цивільному процесі. Цивіліс тична процесуальна думка. 2017. № 1. С. 46-50.

4. Ярошенко I. Малозначні спори: окремі аспекти тлумачення поняття. Малозначні спори: європейський та украӥнський досвід вирішення : збірник наукових праць Міжнародної науково-практичної конференціі (м. Київ, 23-24 листопада 2018 року). Київ : Дакор, 2018. C. $217-221$.

5. Полюк Ю.І. Деякі зміни цивільного процесуального законодавства щодо реалізації права на звернення до суду за захистом: порівняльно-правовий аспект. Форул права. 2018. № 2. С. 98-108.

6. Ткачук О. Сучасні проблеми і напрями спрощення судових процедур у цивільному судочинстві України. Підприємство, господарство і право. 2016. № 5 . C. $19-24$.

7. Швецова Л.А. Проблемні питання розгляду малозначних справ судами. Малозначні спори: європейський та украӥнський досвід вирішення : збірник наукових праць Міжнародної науково-практичної конференції (м. Київ, 23-24 листопада 2018 року). Київ : Дакор, 2018. С. 203-216.

8. Regulation (EU). 2015/2421 of the European Parliament and of the Council. December, 16 2015. Official Journal of the European Union. 2015. L 341/1. URL: https://eur-lex.europa.eu/legal-content/EN/ALL/ ?uri $=$ CELEX $\% 3 \mathrm{~A} 32015 \mathrm{R} 2421$

9. Суярко Т.Д. Спрощені провадження господарського судочинства як механізм забезпечення доступності правосуддя у господарських справах. 25 років господарській юрисдикиї̈ в Україні: досвід та перспективи: матеріали Всеукр. наук.-практ. конф. (м. Харків, 20 травня 2016 року). Харків : Право, 2016. С. 155-158.

10. Масловський С.В. Повноваження суду першої інстанції в господарському судочинстві : автореф. дис. ... канд. юрид. наук: 12.00.04; Донец. юрид. ін-т МВС України. Кривий Ріг, 2020. 244 с.
11. Угриновська О., Гембара Г. Спрощене позовне провадження: законодавча регламентація та проблеми судової практики. Підприємство, господарство і право. 2018 . № 12 . С. $85-89$.

12. Згама А.О. Щодо оптимізації процесуальних форм у господарському процесі: наказне провадження та спрощене позовне провадження. 25 років господарській юрисдикиї в Україні: досвід і перспективи : матеріали Всеукр. наук.- практ. конф. (м. Харків, 20 травня 2016 року). Харків : Право, 2016. С. 52-56.

13. Бєлікова О., Бєлікова Є. Спрощене позовне провадження в господарському процесі та перспективи прискорення захисту прав. Підприєлництво, господарство і право. 2019. № 6. С. 62-67.

14. Іванов 0.0. Спрощене позовне провадження в господарському судочинстві: проблеми пошуку та визначення критеріїв відповідності специфіки спору порядку його розгляду й вирішення. Юридичний науковий електронний журнал. 2019. № 5. С. 95-97. URL: http://www.lsej.org.ua/5_2019/22.pdf.

15. Щербина В., Рєзнікова В. Сучасні тенденції розвитку господарського процесу України. Law of Ukraine. 2017. № 9. С. 9-27.

16. Зуб А. Упрощенное производство как модель гражданского судопроизводства. Проблели законноcmi. 2015. № 131. С. 62-70.

\section{Анотація}

Соловйов О. Л. Особливості розгляду справи у спрощеному позовному провадженні в господарському судочинстві. - Стаття.

У статті досліджено порядок розгляду справи у спрощеному позовному провадженні в господарському судочинстві. Визначено, що існування інституту спрощеного позовного провадження пов'язане з необхідністю оптимізації судочинства з метою розгляду деяких категорій господарських спорів без обтяжливих процедур. Обгрунтовано, що саме прискорений розгляд $€$ основною особливістю спрощеного позовного провадження. Виявлено інші особливості інституту спрощеного позовного провадження, а саме: особлива процесуальна форма, яка грунтується прискореному розгляді справи; розгляд справ залежить від якості та повноти наданих позивачем документів, в тому числі доказів; добровільність застосування зацікавленими особами; визначення передумов розгляду в спрощеному позовному провадженні у процесуальному законодавстві України; особливий порядок застосування доказів; скорочення кількості процесуальних дій або системна зміна способу їх вчинення; звуження процесуальних можливостей суду й учасників процесу; обмеженість застосування щодо визначеного кола справ; завершеність процесуального циклу в межах певної судової інстанції; особливий порядок перегляду судових рішень, ухвалених за результатами розгляду справи.

Наголошено, що спрощене позовне провадження характеризується вилученням деяких стандартних складників, які властиві загальному позовному провадженню (підготовче засідання, судові дебати), але воно все одно відповідає меті судочинства та здійснюється відповідно до встановленої процесуальної форми. Визначено, що подальше удосконалення інституту спрощеного позовного провадження спрямовано на зменшення можливостей для зловживання процесуальними правами сторонами по справі та затягування процесу вирішення справи по суті.

Доведено, що удосконалення інституту спрощеного провадження відповідно до визначених європейських стандартів і принципів сприятиме не тільки ефектив- 
ному та справедливому розгляду справи, а й підвищенню правової культури, відповідальності та сумлінності учасників справи. На законодавчому рівні повинна бути визначена можливість розширення переліку справ, які суд може розглянути в порядку спрощеного позовного провадження.

Ключові слова: господарське судочинство, господарський процес, позовне провадження, спрощене позовне провадження, форми господарського судочинства.

\section{Summary}

Soloviov $0 . L$. Features of consideration of the case in the simplified claim proceedings in commercial litigation. - Article.

The article examines the procedure for consideration of a case in a simplified claim procedure in economic litigation. It is determined that the existence of the institution of simplified litigation is associated with the need to optimize the proceedings in order to consider certain categories of economic disputes without burdensome procedures. It is substantiated that the expedited consideration is the main feature of the simplified claim proceedings.

Other features of the institute of simplified claim proceedings were revealed, namely: a special procedural form, which is based on the accelerated consideration of the case; consideration of cases depends on the quality and completeness of the documents provided by the plaintiff, including evidence; voluntary use by interested parties; determination of preconditions of consideration in the simplified claim proceedings in the procedural legislation of Ukraine; special procedure for the use of evidence; reducing the number of procedural actions or systemic change in the manner of their commission; narrowing the procedural possibilities of the court and participants in the process; limited application to a certain range of cases; completion of the procedural cycle within a certain court; a special procedure for reviewing court decisions made as a result of the case.

It is proved that the improvement of the institution of simplified proceedings, in accordance with the defined European standards and principles, will contribute not only to effective and fair consideration of the case, but also to increase the legal culture, responsibility and integrity of the parties. At the legislative level, the possibility of expanding the list of cases that a court may consider in summary proceedings should be determined.

Key words: economic litigation, economic process, claim proceedings, simplified claim proceedings, forms of economic litigation. 